\title{
PENGARUH PARTISIPASI PENYUSUNAN ANGGARAN, MOTIVASI DAN PELIMPAHAN WEWENANG TERHADAP KINERJA MANAJERIAL DINAS DAERAH KABUPATEN KEPULAUAN SIAU TAGULANDANG BIARO
}

\author{
Oleh : \\ Titien Marthin \\ David Paul Elia Saerang \\ Sifrid S. Pangemanan \\ Magister Akuntansi, Fakultas Ekonomi dan Bisnis \\ Universitas Sam Ratulangi Manado \\ email : titienmarthin@yahoo.com
}

\begin{abstract}
ABSTRAK
Penelitian ini ditujukan untuk menguji pengaruh partisipasi, motivasi, pelimpahan wewenang penyusunan anggaran terhadap kinerja manajerial. Permasalahan umum dalam penelitian ini adalah kurangnya partisipasi staf, kurangnya perhatian pimpinan kepada staf dan kurang maksimalnya pelimpahan wewenang kepada staf dalam penyusunan anggaran sehingga mempengaruhi kinerja manajerial pada Dinas Daerah Kabupaten Kepulauan Siau Tagulandang Biaro. Populasi penelitian adalah para pejabat eselon III dan eselon IV selaku pengguna anggaran pada Dinas Daerah Kabupaten Kepulauan Siau Tagulandang Biaro sebanyak 54 responden. Analisis regresi berganda dengan perangkat lunak Statistical Product and Service Solution (SPSS). Variabel dalam penelitian ini adalah variabel bebas; partisipasi penyusunan anggaran $\left(\mathrm{X}_{1}\right)$, motivasi $\left(\mathrm{X}_{2}\right)$, dan pelimpahan wewenang $\left(\mathrm{X}_{3}\right)$, dan variabel terikat kinerja manajerial $(\mathrm{Y})$. Sebelum pengujian hipotesis dengan uji simultan (uji F) dan uji parsial (uji t), maka dilakukan pengujian instrumen yang meliputi uji asumsi klasik, uji normalitas, uji multikolinearitas, uji heteroskedasitas. Hasil penelitian menunjukkan bahwa motivasi dalam penyusunan anggaran berpengaruh signifikan dan positif terhadap kinerja manajerial, sedangkan variabel partisipasi dan pelimpahan wewenang tidak berpengaruh signifikan terhadap kinerja manajerial pada Dinas Daerah Kabupaten Kepulauan Siau Tagulandang Biaro.
\end{abstract}

Kata Kunci : Partisipasi penyusunan anggaran, motivasi, pelimpahan wewenang, kinerja manajerial.

\begin{abstract}
The aim of this research is to test the effect of participation in budgeting, motivation, and delegation of authority towards performance managerial at the Regency of Siau Tagulandang Biaro Island. The general problem in this study is the lack of participation in budgeting, motivation and delegation of authority thus affecting the managerial performance at Regency of Siau Tagulandang Biaro Island. The population of this research are the $3^{\text {rd }}$ and $4^{\text {th }}$ echelon as much as 54 respondents. Multiple regression analysis by Statistical Product and Service Solution (SPSS). Independent variables in this research are participation in budgeting $\left(\mathrm{X}_{1}\right)$, motivation $\left(\mathrm{X}_{2}\right)$, and delegation of authority $\left(\mathrm{X}_{3}\right)$, and dependent variable is performance managerial at The Regency of Siau Tagulandang Biaro Island. Before hypothesis testing with F-test and t-test, it was done instrument testing covering validity test, reliability test, classical assumptions test, multicolinearity test, normality test, heteroscesdastisity test. The study results that motivation within budgeting have a significant and positive impact on managerial performance, while the participation and delegation of authority did not significantly affect the managerial performance at Regency of Siau Tagulandang Biaro Island.
\end{abstract}

Keywords: Participation in budgeting, motivation, delegation of authority, managerial performance. 


\section{Latar Belakang}

\section{PENDAHULUAN}

Anggaran merupakan pernyataan mengenai estimasi kinerja yang hendak dicapai selama periode waktu tertentu yang dinyatakan dalam satuan moneter. Pada sektor publik, anggaran harus diinformasikan kepada publik untuk dikritik, didiskusikan, dan diberi masukan.

Anggaran pada sektor publik terkait dengan proses penentuan jumlah alokasi dana untuk tiap-tiap program dan aktivitas dalam satuan moneter yang menggunakan dana milik rakyat. Fungsi anggaran adalah sebagai alat perencanaan yang salah satunya digunakan untuk menentukan indikator kinerja. Dalam UndangUndang Nomor 32 Tahun 2004 tentang Pemerintahan Daerah dan Undang-Undang Nomor 33 Tahun 2004 tentang Perimbangan Keuangan antara Pemerintah Pusat dan Pemerintah Daerah membuka peluang yang luas bagi daerah untuk mengembangkan dan membangun daerahnya sesuai dengan kebutuhan dan prioritasnya masing-masing. Pada prinsipnya penyusunan anggaran yang dilaksanakan oleh pemerintah daerah berpedoman pada Peraturan Menteri Dalam Negeri Nomor 13 Tahun 2006 sebagaimana terakhir diubah dengan Peraturan Menteri Dalam Negeri Nomor 21 Tahun 2011, dimana dalam penyusunan rencana keuangan tahunan dilakukan secara terintegrasi untuk seluruh jenis belanja guna melaksanakan kegiatan pemerintahan yang didasarkan pada prinsip pencapaian efisiensi alokasi dana. Penyusunan APBD terpadu selaras dengan penyusunan anggaran yang berorientasi pada anggaran berbasis kinerja atau prestasi kerja. Berdasarkan BPK RI Perwakilan Sulawesi Utara Tahun 2011 Badan Pemeriksa Keuangan memberikan opini Wajar Dengan Pengecualian terhadap LKPD Kabupaten Kepulauan Sitaro. Menurut BPK, Pemerintah Daerah Kabupaten Kepulauan Sitaro dalam menyusun laporan keuangan masih terdapat kelemahan yaitu : pencatatan tidak/belum dilakukan secara akurat, proses penyusunan laporan tidak sesuai dengan ketentuan, entitas terlambat menyampaikan laporan, sistem informasi akuntansi dan pelaporan tidak memadai dan sistem informasi akuntansi dan pelaporan belum didukung SDM yang memadai. Berdasarkan hasil pengamatan dan kenyataan yang ada, rata-rata Dinas Daerah di Kabupaten Kepulauan Sitaro dalam partisipasi penyusunan anggaran dalam pelaksanaanya belum sepenuhnya berjalan efektif, para pelaksana masih kurang berpartisipasi untuk merencanakan anggaran. Sasaran anggaran yang tidak jelas menyebabkan kebingungan, tekanan dan ketidakpastian dari pegawai yang akan berdampak buruk terhadap kinerja. Kinerja akan dikatakan efektif apabila pihak-pihak bawahan mendapat kesempatan terlibat atau berpartisipasi dalam proses penyusunan anggaran. Ketika suatu anggaran dirancang secara partisipatif maka pegawai akan memiliki rasa tanggungjawab pribadi untuk mencapai standar yang ditetapkan karena mereka ikut serta terlibat dalam proses penyusunan yang akan berpengaruh pada tingkat kinerja.

Adanya kesenjangan hubungan antara atasan dengan bawahan, sehingga minimbulkan kurangnya komunikasi yang efektif. Ini terjadi karena sering terjadinya pergantian personil dalam Dinas Daerah Kepulauan Sitaro. Jika hubungan antara atasan dengan bawahan terjalin dengan baik dengan memprioritaskan komunikasi yang efektif, maka keserasian dengan motivasi dalam organisasi dapat berjalan dengan baik pula.

Adanya rasa kurang percaya dari atasan kepada bawahan pada Dinas Daerah di Kabupaten Kepulauan Sitaro dalam pelimpahan wewenang. Pada dasarnya penyelesaian pekerjaan akan dapat dilakukan dengan lebih cepat sekiranya pelimpahan wewenang tersebut berjalan sebagaimana mestinya dan diberikan kepada orang yang bertanggung jawab,selain itu memberikan sub-bagian atau bawahan mempelajari sesuatu yang baru dan memperoleh kesempatan untuk melakukan sesuatu yang baru tersebut sehingga memaksimalan kinerja manajerial. Kinerja manajerial yang dimaksud disini adalah kinerja para pejabat eselon III dan IV Pemerintah Daerah Kabupaten Sitaro karena mereka terlibat langsung dalam penyusunan anggaran sehingga banyak dilibatkan dalam proses perencanaan/penyusunan anggaran, menggunakan dan melaporkan realisasi anggaran atau sebagai pengguna/kuasa pengguna anggaran SKPD, yang menjadikan keberhasilan dan tidak seorang pimpinan dalam menjalankan tugas dan tanggungjawab memimpin dinas.

\section{Tujuan Penelitian}

Penelitian ini bertujuan untuk:

1. Menganalisis pengaruh partisipasi

2. penyusunan anggaran terhadap kinerja manajerial.

3. Menganalisis pengaruh motivasi penyusunan anggaran terhadap kinerja manajerial.

4. Menganalisis pengaruh pelimpahan wewenang dalam penyusunan anggaran, terhadap kinerja manajerial. 


\section{Partisipasi Penyusunan Anggaran}

\section{TINJAUAN PUSTAKA}

Partisipasi dalam proses penganggaran merupakan pendekatan yang efektif untuk meningkatkan motivasi manajer. Dengan tingkat partisipasi yang tinggi cenderung mendorong manajer untuk lebih aktif didalam memahami anggaran dan manajer akan memiliki pemahaman yang baik dalam menghadapi kesulitan pada saat pelaksanaan anggaran. Anggaran yang efektif berhasil harus melibatkan bawahan dalam tanggungjawab pengendalian biaya untuk membuat estimasi anggaran.

Garisson dan Noreen dalam Budisantoso (2000) menyatakan bahwa anggaran partisipatif adalah anggaran yang dibuat dengan kerjasama dan partisipati penuh dari bawahan pada semua tingkatan. Keunggulan yang biasanya diungkapkan atas anggaran partisipatif, yaitu: (1) Setiap orang pada semua tingkatan organisasi diakui sebagai anggota tim yang pandangan dan penilaiannya dihargai oleh manajemen puncak, (2) Orang yang berhubungan langsung dengan suatu aktivitas mempunyai kedudukan terpenting dalam pembuatan estimasi anggaran, (3) Orang lebih cenderung untuk mencapai anggaran yang penyusunannya melibatkan orang lain, (4) Suatu anggaran partisipatif mempunyai sistem pengendalian tersendiri sehingga jika tidak mencapai anggaran, maka yang harus disalahkan adalah diri sendiri dan apabila anggaran didrop dari atas, maka selalu berdalih bahwa anggarannya tidak masuk akal atau tidak realistis diterapkan dan dicapai.

\section{Motivasi}

Anwar (2010) menyatakan bahwa motivasi atau dorongan merupakan kondisi atau energi yang menggerakkan diri karyawan yang terarah atau tertuju untuk mencapai tujuan organisasi perusahaan. Sikap mental karyawan yang pro dan positif terhadap situasi kerja itulah yang memperkuat motivasi karyawan tersebut untuk mencapai kinerja maksimal. Motivasi sangat penting bagi karyawan, manajer atau para pemimpin karena dengan motivasi yang tinggi, maka pekerjaan (tugas) dilakukan dengan bersemangat dan bergairah sehingga akan dicapai suatu hasil yang optimal (prestasi tinggi) yang tentunya akan mendukung tercapainya tujuan yang diinginkan dengan efisien dan efektif.

\section{Pelimpahan Wewenang}

Mulyadi dan Setyawan (2000) dalam Marani dan Supomo (2003) menyatakan bahwa pelimpahan wewenang adalah pemberian wewenang oleh manajer yang lebih tinggi kepada manajer yang lebih rendah untuk melaksanakan suatu pekerjaan dengan otorisasi secara eksplisit dari manajer pemberi wewenang pada waktu wewenang tersebut dilaksanakan. Struktur organisasi yang disertai dengan tingkat pelimpahan wewenang sentralisasi yang tinggi, menunjukkan bahwa semua keputusan yang penting ditentukan pimpinan (manajemen) puncak, sementara manajemen pada tingkat menengah atau bawahannya hanya mempunyai sedikit wewenang dalam pembuatan keputusan.

\section{Kinerja Manajerial}

Anwar (2010) menyatakan bahwa kinerja manajerial merupakan proses perencanaan, pengorganisasian, pelaksanaan, dan pengendalian terhadap pencapaian kinerja dan dikomunikasikan secara terus menerus oleh pimpinan kepada karyawan, antara karyawan dengan atasannya langsung. 


\section{Penelitian Terdahulu}

Tabel 1. Penelitian Terdahulu

\begin{tabular}{|c|c|c|c|c|c|}
\hline $\begin{array}{l}\text { Nama } \\
\text { Peneliti/ } \\
\text { Tahun }\end{array}$ & Judul & $\begin{array}{l}\text { Metode } \\
\text { Penelitian }\end{array}$ & $\begin{array}{l}\text { Hasil } \\
\text { Penelitian }\end{array}$ & Persamaan & Perbedaan \\
\hline $\begin{array}{l}\text { Utami } \\
(2009)\end{array}$ & $\begin{array}{l}\text { Pengaruh Pelimpahan } \\
\text { Wewenang Dan Motivasi } \\
\text { Terhadap Hubungan Antara } \\
\text { Partisipasi } \\
\text { Penyusunan Anggaran Dengan } \\
\text { Kinerja Manajerial } \\
\text { (Survey Pada Pejabat Struktural } \\
\text { Di Skpd Pemerintah Kabupaten } \\
\text { Klaten) }\end{array}$ & $\begin{array}{l}\text { Pengembangan } \\
\text { deskripsi kasus }\end{array}$ & $\begin{array}{l}\text { Pengaruh } \\
\text { pelimpahan } \\
\text { wewenang } \\
\text { dan motivasi } \\
\text { berpengaruh } \\
\text { positif } \\
\text { terhadap } \\
\text { kinerja } \\
\text { Manajerial }\end{array}$ & $\begin{array}{l}\text { Peneliti } \\
\text { sebelumnya } \\
\text { melakukan } \\
\text { dengan variabel } \\
\text { yang sama yaitu } \\
\text { pelimpahan } \\
\text { wewenang dan } \\
\text { motivasi }\end{array}$ & $\begin{array}{l}\text { Peneliti } \\
\text { menambahkan } \\
\text { satu variabel } \\
\text { independed } \\
\text { yaitu partisipasi } \\
\text { penyusunan } \\
\text { anggaran }\end{array}$ \\
\hline $\begin{array}{l}\text { Hapsari } \\
(2010)\end{array}$ & $\begin{array}{lr}\text { Pengaruh } & \text { Partisipasi } \\
\text { Penyusunan } & \text { Anggaran } \\
\text { Terhadap Kinerja Manajerial } \\
\text { dengan komitmen organisasi } \\
\text { dan locus of control sebagai } \\
\text { variabel moderating }\end{array}$ & $\begin{array}{l}\text { Pengembangan } \\
\text { deskripsi kasus }\end{array}$ & $\begin{array}{l}\text { Partisipasi } \\
\text { anggaran } \\
\text { berpengaruh } \\
\text { positif } \\
\text { terhadap } \\
\text { kinerja } \\
\text { Manajerial. }\end{array}$ & $\begin{array}{l}\text { Peneliti } \\
\text { sebelumnya } \\
\text { melakukan } \\
\text { penelitian } \\
\text { terhadap faktor } \\
\text { yang sama yaitu } \\
\text { Pengaruh } \\
\text { Partisipasi } \\
\text { Penyusunan } \\
\text { Anggaran } \\
\text { Terhadap } \\
\text { Kinerja } \\
\text { Manajerial }\end{array}$ & $\begin{array}{l}\text { Peneliti ingin } \\
\text { meneliti lebih } \\
\text { lanjut tentang } \\
\text { pengaruh } \\
\text { faktor-faktor } \\
\text { tersebut } \\
\text { terhadap } \\
\text { motivasi kerja } \\
\text { dan pelimbahan } \\
\text { wewenang }\end{array}$ \\
\hline Hafiz (2007) & $\begin{array}{l}\text { Pengaruh partisipasi anggaran } \\
\text { terhadap kinerja Manajerial } \\
\text { pada PT Cakra Compact } \\
\text { Aluminium Industries }\end{array}$ & Deskriptif & $\begin{array}{l}\text { Partisipasi } \\
\text { anggaran } \\
\text { berpengaruh } \\
\text { positif } \\
\text { terhadap } \\
\text { kinerja } \\
\text { Manajerial }\end{array}$ & $\begin{array}{l}\text { Menguraikan } \\
\text { bahwa } \\
\text { partisipasi } \\
\text { mempunyai } \\
\text { pengaruh positif } \\
\text { terhadap kinerja } \\
\text { Manajerial }\end{array}$ & $\begin{array}{l}\text { Peneliti } \\
\text { mencoba untuk } \\
\text { memaparkan } \\
\text { lebih lanjut } \\
\text { mengenai faktor } \\
\text { kinerja } \\
\text { Manajerial } \\
\text { dalam kaitannya } \\
\text { dengan } \\
\text { motivasi, dan } \\
\text { pelimpahan } \\
\text { wewenang. }\end{array}$ \\
\hline $\begin{array}{l}\text { Desi Winarni } \\
2013\end{array}$ & $\begin{array}{l}\text { Pengaruh Partisipasi Dalam } \\
\text { Penyusunan } \\
\text { Motivasi, Anggaran, } \\
\text { Wewenang, Budaya Organisasi } \\
\text { terhadap Kinerja Manajerial } \\
\text { (Studi Kasus Pada Dinas } \\
\text { Dilingkungan } \\
\text { Muaro Jambi) }\end{array}$ & $\begin{array}{l}\text { Pengembangan } \\
\text { deskripsi kasus }\end{array}$ & $\begin{array}{l}\text { Pengaruh } \\
\text { pelimpahan } \\
\text { wewenang, } \\
\text { motivasi, } \\
\text { penyusunan } \\
\text { anggaran dan } \\
\text { budaya } \\
\text { organisasi } \\
\text { berpengaruh } \\
\text { dan motivasi } \\
\text { positif } \\
\text { terhadap } \\
\text { kinerja } \\
\text { Manajerial }\end{array}$ & $\begin{array}{l}\text { Peneliti } \\
\text { sebelumnya } \\
\text { melakukan } \\
\text { dengan variabel } \\
\text { yang sama yaitu } \\
\text { pelimpahan } \\
\text { wewenang, } \\
\text { motivasi dan } \\
\text { partisipasi } \\
\text { penyusuhan } \\
\text { anggaran }\end{array}$ & $\begin{array}{l}\text { Peneliti } \\
\text { menambahkan } \\
\text { satu variabel } \\
\text { indipenden } \\
\text { yaitu budaya } \\
\text { organisasi }\end{array}$ \\
\hline
\end{tabular}




\begin{tabular}{|c|c|c|c|c|c|}
\hline $\begin{array}{l}\text { Soetrisno } \\
2010\end{array}$ & $\begin{array}{l}\text { Pengaruh Partisipasi, Motivasi, } \\
\text { dan Pelimpahan Wewenang, } \\
\text { Dalam Penyusunan Anggaran } \\
\text { Terhadap Kinerja Manajerial. } \\
\text { Studi Empiris Pada Dinas } \\
\text { Daerah dan Lembaga Teknis } \\
\text { Daerah di Kabupaten Rembang. } \\
\text { Universitas Diponegoro }\end{array}$ & $\begin{array}{l}\text { Pengembangan } \\
\text { deskripsi kasus }\end{array}$ & $\begin{array}{l}\text { Partisipasi } \\
\text { anggaran } \\
\text { berpengaruh } \\
\text { dan } \\
\text { pelimpahan } \\
\text { wewenang } \\
\text { berpengaruh } \\
\text { positif } \\
\text { terhadap } \\
\text { kinerja } \\
\text { Manajerial. }\end{array}$ & $\begin{array}{l}\text { Peneliti } \\
\text { sebelumnya } \\
\text { melakukan } \\
\text { penelitian } \\
\text { terhadap faktor } \\
\text { yang sama yaitu } \\
\text { Pengaruh } \\
\text { Partisipasi } \\
\text { Penyusunan } \\
\text { Anggaran } \\
\text { Terhadap } \\
\text { Kinerja } \\
\text { Manajerial }\end{array}$ & $\begin{array}{l}\text { Peneliti ingin } \\
\text { meneliti lebih } \\
\text { lanjut tentang } \\
\text { pengaruh } \\
\text { faktor-faktor } \\
\text { tersebut } \\
\text { terhadap } \\
\text { motivasi kerja } \\
\text { dan pelimpahan } \\
\text { wewenang }\end{array}$ \\
\hline
\end{tabular}

\section{KERANGKA KONSEPTUAL}

\section{Kerangka Konseptual Penelitian}

Berdasarkan latar belakang, tinjauan pustaka dengan teori-teori yang telah dijelaskan, maka kerangka pikir dari penelitian ini adalah sebagai berikut:

\section{Gambar 1. Kerangka Pikir Penelitian}

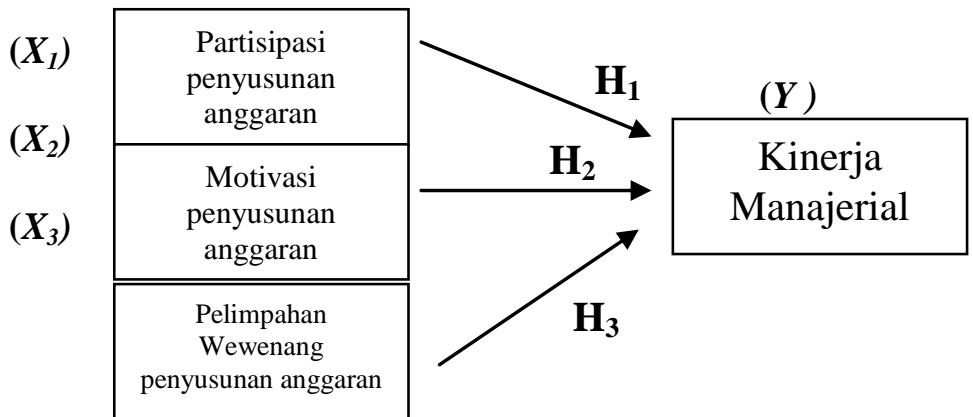

Sumber data: Data sekunder hasil olahan (2013)

\section{Hipotesis}

$\mathrm{H}_{\mathrm{a}} 1$ : Partisipasi penyusunan anggaran berpengaruh positif terhadap kinerja manajerial Dinas Daerah

Kabupaten Kepulauan Siau Tagulandang Biaro?

$\mathrm{H}_{\mathrm{a}} 2$ : $\quad$ Motivasi penyusunan anggaran berpengaruh positif terhadap kinerja manajerial Dinas Daerah di

Kabupaten Kepulauan Siau Tagulandang Biaro?

$\mathrm{H}_{\mathrm{a}} 3$ : Pelimpahan wewenang penyusunan anggaran berpengaruh positif terhadap kinerja manajerial Dinas

Daerah di Kabupaten Kepulauan Siau Tagulandang Biaro?

\section{Jenis/Rancangan Penelitian yang Digunakan}

\section{METODE PENELITIAN}

Jenis/rancangan penelitian yang digunakan adalah penelitian penjelasan (explanatory/confirmatory research), karena penelitian ini bermaksud untuk menjelaskan hubungan kausal antara variabel-variabel dengan melalui pengujian hipotesis yang telah dirumuskan sebelumnya. Data yang digunakan dalam penelitian ini adalah kuantitatif.

\section{Populasi, Sampel, Besar Sampel, dan Teknik Pengambilan Sampel}

Populasi dalam penelitian ini adalah unsur pimpinan dan staf Dinas Daerah di Kabupaten Kepulauan Siau Tagulandang Biaro (Sitaro). Populasi dalam penelitian ini adalah sebanyak 13 (tiga belas) SKPD yang terdapat di Kabupaten Sitaro. Alasan pemilihan Kabupaten Kepulauan Sitaro sebagai lokasi penelitian adalah karena masih terdapatnya berbagai permasalahan di Dinas Daerah terkait dengan partisipasi, motivasi,dan pelimpahan wewenang para pengguna anggaran.

\section{Instrumen Penelitian}

Dalam penelitian ini menggunakan kuesioner yang telah dilakukan uji validitas dan reliabilitas oleh para peneliti terdahulu sehingga tidak perlu dilakukan pengujian kembali. 


\section{Lokasi dan Waktu Penelitian}

Penelitian ini dilakukan pada 13 Dinas Daerah di Kabupaten Siau Tagulandang Biaro (Sitaro) pada bulan November 2012 sampai dengan bulan Januari 2013.

\section{Prosedur Pengambilan atau Pengumpulan Data}

Untuk mendapatkan data tentang variabel-variabel yang akan diungkapkan dalam penelitian ini, teknik pengumpulan data dan informasi melalui tahap-tahap sebagai berikut :

1. Menyebarkan kuesioner kepada 70 responden yang ada di SKPD Kabupaten Kepulauan Siau Tagulandang Biaro dengan cara mengantar langsung kepada responden.

2. Setelah batas waktu yang ditentukan, kuisioner diambil kembali. Jumlah kuesioner yang kembali sebanyak 54 kuisioner. Pengisian kuisioner semuanya lengkap.

3. Melakukan wawancara kepada SKPD yang bersedia untuk mengkonfirmasi kembali kuisioner yang telah diisi.

\section{Cara Pengolahan dan Analisis Data}

1. Uji Asumsi Klasik

2. Uji Statistik Deskriptif

3. Analisis Regresi Berganda (Multiple Regression Analysis)

4. Uji Hipotesis

\section{Gambaran Umum Responden}

\section{ANALISIS DAN PEMBAHASAN HASIL PENELITIAN}

Data yang digunakan dalam penelitian ini merupakan data primer yang diperoleh dengan menggunakan daftar pertanyaan (kuesioner) yang telah dikirimkan langsung kepada para pejabat eselon III dan IV dinas daerah di Kabupaten Kepulauan Siau Tagulandang Biaro (Sitaro) pada tanggal 1 November 2012 sampai dengan batas akhir pengembalian yakni tanggal 31 Januari 2013. Dari 70 kuesioner yang telah disebarkan, 54 kuesioner telah dikembalikan dan 16 kuesioner tidak kembali. Tingkat pengembalian (response rate) yang diperoleh adalah $77,2 \%$ sedangkan sisanya $22,8 \%$ tidak kembali karena alasan yang tidak jelas. Tingkat pengembalian ini relatif tinggi karena penyebaran dan pengambilan kembali kuesioner dilakukan dengan cara diantar dan dijemput langsung. Penelitian ini menggunakan instrumen kuesioner yang telah dilakukan uji validitas dan reliabilitas oleh Soetrisno (2010) yang dinyatakan valid dan reliabel.

\section{Uji Asumsi Klasik}

\section{Uji Normalitas}

Grafik Normal P-P Plot of regression standardized residual menggambarkan penyebaran data tersebar di sekitar garis diagonal dan penyebarannya mengikuti arah garis diagonal grafik tersebut, maka model regresi yang digunakan dalam penelitian ini telah memenuhi asumsi normalitas.

\section{Uji Heteroskedastisitas}

Titik-titik grafik plot yang diperoleh tidak membentuk suatu pola yang jelas, serta titik-titik menyebar di atas dan di bawah angka 0 (nol) pada sumbu Y, maka hal ini membuktikan tidak terjadi heteroskedastisitas.

\section{Uji Multikoleniaritas}

Hasil dari perhitungan menghasilkan nilai VIF untuk variabel Partisipasi Penyusunan Anggaran $\left(\mathrm{X}_{1}\right)$ adalah sebesar 1,118 < 10 dan nilai tolerance $0,895>10$, Motivasi $\left(\mathrm{X}_{2}\right)$ adalah sebesar $1,041<10$ dan nilai tolerance $0,961>0,10$, Pelimpahan Wewenang $\left(\mathrm{X}_{3}\right)$ adalah sebesar $1,131<10$ dan nilai tolerance $0,884>0,10$ maka dapat disimpulkan bahwa tidak terjadi gejala multikolinearitas dalam model penelitian ini.

\section{Koefisien Korelasi (r)}

Analisis ini digunakan untuk mengukur kekuatan dan arah hubungan antara variabel bebas (X) terhadap variabel terikat (Y). Dalam hal ini mengukur ada tidaknya hubungan antara Pengaruh Partisipasi Penyusunan Anggaran $\left(\mathrm{X}_{1}\right)$, Motivasi $\left(\mathrm{X}_{2}\right)$, Pelimpahan Wewenang $\left(\mathrm{X}_{3}\right)$ terhadap Kinerja Manajerial. 
Tabel 2. Correlations

\begin{tabular}{|l|l|l|}
\hline & Kinerja Manajerial \\
\hline Pearson Correlation & Kinerja Manajerial & 1.000 \\
& Partisipasi Penyusunan Anggaran & .247 \\
& Motivasi & 436 \\
& Pelimpahan Wewenang & .216 \\
& Kinerja Manajerial & \\
& Partisipasi Penyusunan Anggaran & .036 \\
& Motivasi & .000 \\
& Pelimpahan Wewenang & .058 \\
\hline Ninerja Manajerial & 54 \\
& Partisipasi Penyusunan Anggaran & 54 \\
& & \\
& Motivasi & 54 \\
& Pelimpahan Wewenang & 54 \\
\hline
\end{tabular}

Sumber Data: Hasil Olahan SPSS (2013)

Hasil olahan data menunjukkan bahwa variabel Partisipasi Penyusunan Anggaran $\left(X_{1}\right)$ mempunyai korelasi sangat lemah, positif dan tidak signifikan dengan Kinerja Manajerial (Y). Hal ini ditunjukkan dengan nilai koefisien korelasi 0,247 < 0,25 artinya apabila Partisipasi Penyusunan Anggaran $\left(\mathrm{X}_{1}\right)$ naik, maka Kinerja Manajerial (Y) akan naik pula, demikian sebaliknya. Koefisien korelasi 0,247 bersifat lemah karena Partisipasi Penyusunan Anggaran akan lebih kuat hubungannya apabila terdapat koordinasi yang baik antara penanggungjawab fungsi dan pelaksana fungsi di lapangan.

Untuk variabel Motivasi $\left(\mathrm{X}_{2}\right)$ mempunyai korelasi yang bersifat cukup, positif dan signifikan dengan Kinerja Manajerial (Y) dengan nilai koefisien korelasi sebesar $0,436<0,500$ hal ini berarti apabila Motivasi $\left(\mathrm{X}_{2}\right)$ naik, maka Kinerja Manajerial (Y) akan naik pula, demikian sebaliknya. Koefisien korelasi 0,436 bersifat cukup karena motivasi memiliki hubungan yang lebih kuat dengan kinerja manajerial dibandingkan partisipasi penyusunan anggaran. Untuk variabel Pelimpahan Wewenang $\left(\mathrm{X}_{3}\right)$ mempunyai korelasi yang bersifat lemah, positif dan tidak signifikan dengan Kinerja Manajerial (Y) dengan nilai koefisien korelasi sebesar 0,216 < 0,500 hal ini berarti apabila Pelimpahan Wewenang $\left(\mathrm{X}_{3}\right)$ naik, maka kinerja manajerial (Y) akan naik pula, demikian sebaliknya. Pelimpahan wewenang akan lebih kuat hubungannya dengan kinerja manajerial apabila pemberi wewenang memberikan pelimpahan yang terinci dan jelas kepada penerima wewenang terkait dengan proses penyusunan anggaran Dinas Daerah di Kabupaten Kepulauan Siau Tagulandang Biaro (Sitaro).

\section{Koefisien Determinasi}

Tabel 3. Koefisien Determinasi Model Summary ${ }^{b}$

\begin{tabular}{|l|l|l|l|l|}
\hline Model & $\mathrm{R}$ & R Square & $\begin{array}{l}\text { Adjusted } \\
\text { Square }\end{array}$ & $\begin{array}{l}\text { Std. Error of } \\
\text { the Estimate }\end{array}$ \\
\hline 1 & $.483^{\mathrm{a}}$ & .233 & .187 & 2.929 \\
\hline
\end{tabular}

Sumber Data: Hasil Olahan SPSS (2013)

Besarnya adjusted $\mathrm{R}^{2}$ (koefisien determinasi yang telah disesuaikan) adalah 0,187 . Nilai ini menunjukkan bahwa $18,7 \%$ variasi kinerja manajerial dapat dijelaskan oleh variasi dari ketiga variabel independen yaitu partisipasi, motivasi, dan pelimpahan wewenang, sedangkan sisanya 82,3\% dijelaskan oleh sebab lain di luar model seperti lingkungan kerja, budaya organisasi, kompensasi atau insentif, dan kepuasan kerja.

\section{Analisis Regresi Berganda}

$Y=6.320+0,135 X_{1}+0,338 X_{2}+0,112 X$ 
Tabel 4. Koefisien Regresi

\begin{tabular}{|ll|l|l|}
\hline \multirow{2}{*}{ Model } & & \multicolumn{2}{|l|}{ Unstandardized Coefficients } \\
\cline { 3 - 4 } & & B & Std. Error \\
\hline 1 & (Constant) & 6.320 & 3.099 \\
& PARTISIPASI & .135 & .110 \\
& PENYUSUNAN & & \\
& ANGGARAN & & .108 \\
& MOTIVASI & .338 & .154 \\
& PELIMPAHAN & .112 & \\
WEWENANG & & \\
\hline
\end{tabular}

Sumber : Data Hasil Olahan SPSS (2013)

Nilai koefisien regresi dari variabel Partisipasi Penyusunan Anggaran $\left(b_{1}\right)$ adalah positif sebesar 0,135. Nilai koefisien regresi $b_{1}$ ini menunjukkan bahwa variabel partisipasi penyusunan anggaran mempunyai pengaruh positif dan searah terhadap kinerja manajerial secara statistik. Hal in berarti bahwa apabila partisipasi penyusunan anggaran meningkat, maka kinerja manajerial Dinas Daerah di Kabupaten Kepulauan Siau Tagulandang Biaro (Sitaro) akan meningkat pula.

Nilai koefisien regresi dari variabel Motivasi atau $\left(b_{2}\right)$ adalah positif sebesar 0,338 . Nilai koefisien regresi $b_{2}$ ini menunjukkan bahwa pengaruh hubungan variabel motivasi terhadap kinerja manajerial adalah positif dan searah. Dengan demikian, apabila motivasi meningkat, maka kinerja manajerial Dinas Daerah di Kabupaten Kepulauan Siau Tagulandang Biaro (Sitaro) akan meningkat.

Koefisien regresi dari variabel pelimpahan wewenang $\left(b_{3}\right)$ memiliki nilai positif sebesar 0,112 dimana nilai koefisien regresi $b_{3}$ ini menunjukkan bahwa variabel pelimpahan wewenang berpengaruh positif dan searah terhadap kinerja manajerial secara statistik. Dengan demikian apabila terjadi peningkatan pada pelimpahan wewenang, maka kinerja manajerial Dinas Daerah di Kabupaten Kepulauan Siau Tagulandang Biaro (Sitaro) akan meningkat.

Pengujian Hipotesis Parsial (Uji t)

Tabel 5. Rangkuman Hasil Uji Hipotesis Variabel

\begin{tabular}{|l|l|l|l|}
\hline No & Variabel Hasil & Keterangan \\
\hline 1 & $\begin{array}{l}\text { Partisipasi Penyusunan Anggaran terhadap Kinerja } \\
\text { Manajerial }\end{array}$ & $\mathrm{H}_{1}$ ditolak & $0,223>0,05$ \\
\hline 2 & Motivasi terhadap Kinerja Manajerial & $\mathrm{H}_{2}$ diterima & $0,03<0,05$ \\
\hline 3 & Pelimpahan Wewenang terhadap Kinerja Manajerial & $\mathrm{H}_{3}$ ditolak & $0,470>0,05$ \\
\hline
\end{tabular}

Sumber Data: Hasil Olahan SPSS (2013)

\section{Pengujian Hipotesis Simultan (Uji F)}

Tabel 6. ANOVA ${ }^{b}$

\begin{tabular}{|ll|l|l|l|l|l|}
\hline Model & & Sum of Squares & Df & Mean Square & F & Sig. \\
\hline 1 & Regression & 130.380 & 3 & 43.460 & 5.066 & $.004^{\mathrm{a}}$ \\
& Residual & 428.953 & 50 & 8.579 & & \\
& Total & 559.333 & 53 & & & \\
\hline
\end{tabular}

Sumber Data: Hasil Olahan SPSS (2013)

Dari tabel 6 Hasil pengujian statistik secara simultan atau bersama-sama (Uji F) menyangkut Partisipasi Penyusunan Anggaran, Motivasi, dan Pelimpahan Wewenang terhadap Kinerja Manajerial Dinas Daerah di Kabupaten Kepulauan Siau Tagulandang Biaro diperoleh nilai $F_{\text {hitung }}=5,0662$. Angka ini lebih besar dari $F_{\text {tabel }}$ $=2,79$ pada tingkat $\alpha=0,05$. Dengan demikian maka dapat disimpulkan bahwa $\mathrm{H}_{\mathrm{o}}$ ditolak dan $\mathrm{H}_{\mathrm{a}}$ diterima. Hal ini berarti, Partisipasi penyusunan anggaran $\left(\mathrm{X}_{1}\right)$, Motivasi $\left(\mathrm{X}_{2}\right)$, Pelimpahan Wewenang $\left(\mathrm{X}_{3}\right)$, secara bersamasama berpengaruh Kinerja Manajerial (Y).

\section{Pembahasan}

Pengaruh Partisipasi Penyusunan Anggaran terhadap Kinerja Manajerial Dinas Daerah di Kabupaten Kepulauan Siau Tagulandang Biaro (Sitaro)

Secara parsial, partisipasi penyusunan anggaran tidak berpengaruh terhadap kinerja manajerial Dinas Daerah di Kabupaten Kepulauan Siau Tagulandang Biaro (Sitaro).. Hasil Kontribusi terbesar dari kegiatan 
penganggaran terjadi bila bawahan diperbolehkan untuk berpartisipasi dalam kegiatan penyusunan anggaran. Partisipasi penyusunan anggaran merupakan keterlibatan pimpinan dan staf dalam Dinas Daerah di Kabupaten Kepulauan Sitaro untuk melakukan kegiatan dalam pencapaian sasaran yang telah ditetapkan sebelumnya. Dengan adanya keterlibatan tersebut akan mendorong para sekretaris/kepala bidang dan kepala sub bagian/kepala sub bidang untuk bertanggungjawab terhadap tugas yang diembannya sehingga mereka akan meningkatkan kinerja manajerialnya guna mencapai target/sasaran yang telah ditetapkan dalam anggaran.

Akan tetapi, analisis hasil penelitian ini mengumpulkan bukti empirik yang berbeda dengan kondisi ideal tersebut. Kondisi ini bisa dimaklumi karena Kabupaten Kepulauan Siau Tagulandang Biaro (Sitaro) adalah daerah hasil pemekaran yang baru berkembang sehingga dalam penyusunan anggaran masih kurang melibatkan partisi-pasi dari staf lainnya. Selain itu juga belum ada aturan konkrit yang dibuat untuk menjamin partisipasi dan kerjasama dari pejabat yang berwenang dan staf. Agar mencapai efektivitas partisipasi penyusunan anggaran, maka tingkat partisipasi tersebut harus memiliki indikator input dan output riil terhadap keputusan dan pandangan mereka harus memiliki bobot tertentu dalam hasil akhir.

Jika partisipasi penyusunan anggaran mengalami penolakan oleh level pimpinan yang lebih tinggi tanpa penjelasan sama sekali, atau dengan argumen yang nyata bahwa saran tersebut tidak sesuai dengan tujuan, maka partisipasi akan dipandang sebagai suatu kepura-puraan sehingga menimbulkan kekecewaan. Apabila hal ini terjadi, sikap negatif atau bermusuhan terhadap manajemen puncak (top management) akan berkembang sehingga memberikan sinyal adanya penurunan kinerja manajerial Dinas Daerah di Kabupaten Kepulauan Siau Tagulandang Biaro (Sitaro).

Hasil penelitian ini sejalan dengan penelitian dari Sarikoski (2006) yang mengemukakan bahwa penyusunan anggaran tidak berpengaruh terhadap kinerja manajerial. Hasil penelitian Marchant (1981) dalam Ritonga (2008) menyimpulkan terdapat hubungan negatif antara anggaran partisipatif dan kinerja manajerial dapat terjadi akibat tingkat partisipasi yang tinggi berdampak terhadap menurunnya kinerja yang disebabkan oleh adanya pengaruh budgetary slack. Hal ini menunjukkan bahwa para Kepala Dinas Daerah di Kabupaten Kepulauan Siau Tagulandang Biaro (Sitaro) sering mengikutsertakan pejabat eselon III dan IV dalam proses penyusunan anggaran. Keikutsertaan para sekretaris, kepala bidang, kepala sub bagian, dan kepala seksi ini penting dalam upaya memotivasi bawahan untuk turut serta mencapai visi dan misi pembangunan daerah. Partisipasi memungkinkan terjadinya komunikasi yang semakin baik, interaksi satu sama lain serta bekerja sama dalam tim untuk mencapai tujuan organisasi. Hasil penelitian ini tidak mendukung penelitian yang telah dilakukan oleh Schuler \& Kim (1976), Brownell (1982), Brownell dan Mc. Innes (1986), Nur Indriantoro (1993) sebagaimana dikutip oleh Sardjito dan Muthaher (2007).

\section{Pengaruh Motivasi terhadap Kinerja Manajerial Dinas Daerah di Kabupaten Kepulauan Siau Tagulandang Biaro (Sitaro)}

Secara parsial, motivasi berpengaruh terhadap kinerja manajerial, dari hasil penelitian nampak betapa motivasi yang diberikan kepala SKPD kepada pejabat eselon III dan IV serta bawahannya sangat mempengaruhi kinerja manajerial. Motivasi yang diberikan dalam bentuk penghargaan/imbalan serta keamanan dan kenyamanan kerja. Berbagai pekerjaan operasional maupun manajerial akan terasa lebih ringan, dengan adanya dukungan dari para staf Dinas Daerah di Kabupaten Kepulauan Siau Tagulandang Biaro (Sitaro). Pentingnya peran staf terhadap pencapaian visi dan misi daerah, mendorong para kepala SKPD untuk selalu memotivasi para staf agar bisa bekerja secara optimal. Sebab, semakin bagus kinerja yang diberikan para karyawan, maka semakin besar pula peluang bagi pemerintah daerah untuk mencapai kesuksesannya.

Hasil penelitian menemukan bahwa ke-13 Dinas Daerah di Kabupaten Kepulauan Siau Tagulandang Biro (Sitaro) telah memiliki bawahan yang mampu, cakap dan terampil serta mau bekerja giat dan berkeinginan untuk mencapai hasil kerja yang optimal. Akan tetapi, kemampuan, kecakapan dan keterampilan karyawan atau pegawai harus ditunjang pula oleh motivasi untuk bekerja keras dengan mempergunakan kemampuan, kecakapan dan ketrampilan yang dimiliki. Temuan ini menunjukkan bahwa motivasi dapat meningkatkan kinerja manajerial dalam suatu organisasi Elemen motivasi ini bisa datang dari dalam diri sendiri dan juga motivasi dari atasan untuk kemajuan kinerja manajerial. Pengaruh motivasi dalam penelitian ini mengindikasikan bahwa pejabat dan staf yang berwenang telah memiliki motivasi yang tinggi sehingga bersedia untuk memberikan kontribusi yang sebesar mungkin demi keberhasilan organisasi mencapai tujuannya. Dengan demikian bahwa tercapainya tujuan organisasi berarti tercapai pula tujuan pribadi para anggota organisasi yang bersangkutan dan secara tidak langsung meningkatkan kinerja manajerial dari lembaga terkait yang ada di Kabupaten Kepulauan Siau Tagulandang Biaro (Sitaro). 


\section{Pengaruh Pelimpahan Wewenang terhadap Kinerja Manajerial Dinas Daerah di Kabupaten Kepulauan Siau Tagulandang Biaro (Sitaro)}

Secara parsial, pelimpahan wewenang tidak mempunyai hubungan dengan kinerja manajerial, hasil temuan ini berbeda dari penelitian terdahulu yang menemukan bahwa pelimpahan wewenang mempunyai hubungan dengan kinerja manajerial. Pelimpahan wewenang dalam organisasi berkaitan erat dengan struktur organisasi. Struktur organisasi memberikan gambaran mengenai pembagian kekuasaan dalam suatu organisasi. Riyanto (1996) dalam Ardiani, Triyani, dan Lestari (2011) menyatakan bahwa struktur organisasi yang disertai dengan tingkat pelimpahan wewenang yang tinggi menunjukkan bahwa semua keputusan yang penting akan ditentukan Kepala SKPD untuk menghubungkan sistem anggaran dengan pelimpahan wewenang dalam struktur organisasi yang akan menentukan kinerja manajerial. Menurut Gul et al. (1995) dalam Ardiani, Triyani, dan Lestari (2011) partisipasi penyusunan anggaran terhadap kinerja manajerial akan berpengaruh positif dalam organisasi yang pelimpahan wewenangnya bersifat desentralisasi, dan akan berpengaruh negatif dalam organisasi yang bersifat sentralisasi.

Elemen pelimpahan wewenang ini, berdasarkan temuan didapati bahwa tidak adanya hubungan sehingga tidak meningkatkan kinerja manajerial Dinas Daerah di Kabupaten Kepulauan Siau Tagulandang Biaro (Sitaro). Ini terjadi karena kurang maksimalnya pelimpahan wewenang terhadap staff sehingga mengurangi ruang gerak staf untuk lebih kreatif, inovatif dan aktif dalam pemilihan dan pemindahan staf sesuai dengan keahlian (skill). Selain itu, adanya pengalokasian anggaran dan keputusan atasan yang tidak sesuai dengan kebutuhan sehingga kurang memberikan hasil dan manfaat untuk organisasi sehingga kinerja manajerial tidak tercapai dengan maksimal.

\section{Pengaruh Partisipasi Penyusunan Anggaran, Motivasi, dan Pelimpahan Wewenang terhadap Kinerja Manajerial}

Hasil pengujian statistik uji simultan atau bersama-sama (Uji F) menyangkut pengaruh partisipasi penyusunan anggaran, motivasi, dan pelimpahan wewenang terhadap kinerja manajerial Dinas Daerah di Kabupaten Kepulauan Siau Tagulandang Biaro (Sitaro) diperoleh angka $F_{\text {hitung }}(5,066)>F_{\text {tabel }}(2,79)$ dengan sig. hitung 0,000<0,05 $(\alpha: 5 \%)$. Hal ini berarti bahwa Partisipasi Penyusunan Anggaran, Motivasi, dan Pelimpahan Wewenang secara bersama-sama mempunyai pengaruh terhadap Kinerja Manajerial Dinas Daerah di Kabupaten Kepulauan Siau Tagulandang Biaro (Sitaro).

Besarnya adjusted $\mathrm{R}^{2}$ (koefisien determinasi yang telah disesuaikan) adalah 0,187 . Nilai ini menunjukkan bahwa 18,7\% variasi kinerja manajerial dapat dijelaskan oleh variasi dari ketiga variabel independen yaitu partisipasi, motivasi, dan pelimpahan wewenang, sedangkan sisanya 82,3\% dijelaskan oleh faktor-faktor lain di luar model, seperti lingkungan kerja, budaya organisasi, kompensasi atau insentif, dan kepuasan kerja.

Berdasarkan hasil uji statistik atas persamaan regresi diketahui bahwa variabel motivasi penyusunan anggaran memiliki pengaruh paling besar terhadap kinerja manajerial Dinas Daerah di Kabupaten Kepulauan Siau Tagulandang Biaro (Sitaro). Variabel berikutnya adalah variabel partisipasi penyusunan anggaran, kemudian variabel pelimpahan wewenang penyusunan anggaran. Dengan kata lain, kinerja manajerial dilatarbelakangi oleh motivasi yang tinggi dalam proses penyusunan anggaran. Adanya motivasi akan memacu partisipasi staf dalam proses penyusunan anggaran, namun hal ini harus ditunjang oleh kepercayaan dari atasan berupa pelimpahan wewenang. Dengan demikian, hal ini dapat berkontribusi terhadap kesuksesan dalam jenjang karir guna mendukung pelaksanaan tugas dengan baik dan benar.

\section{Kesimpulan}

\section{SIMPULAN DAN SARAN} berikut.

Berdasarkan hasil penelitian dan pembahasan maka dapat disimpulkan beberapa kesimpulan sebagai

1. Nilai dari variabel Partisipasi Penyusunan Anggaran atau $b_{1}$ adalah positif $(0,135)$. Nilai koefisien regresi $b_{1}$ ini menunjukkan bahwa variabel Partisipasi Penyusunan Anggaran mempunyai pengaruh hubungan positif dan searah terhadap Kinerja Manajerial secara statistik.

2. Pengujian hipotesis 1 , diperoleh hasil $t_{\text {hitung }}<t_{\text {tabel, }}$, dengan demikian $H_{a} 1$ ditolak atau dengan kata lain variabel Partisipasi Penyusunan Anggaran tidak berpengaruh signifikan terhadap Kinerja Manajerial Dinas Daerah di Kabupaten Siatro.

3. Nilai dari Motivasi atau $b_{2}$ adalah positif $(0,338)$. Nilai koefisien regresi $b_{2}$ ini menunjukkan bahwa variabel Motivasi mempunyai pengaruh hubungan positif dan searah terhadap Kinerja Manajerial secara statistik.

4. Pengujian hipotesis 2, diperoleh hasil $t_{\text {hitung }}>t_{\text {tabel }}$, dengan demikian $\mathrm{H}_{\mathrm{a}} 2$ diterima atau dengan kata lain variabel Motivasi berpengaruh signifikan terhadap Kinerja Manajerial Dinas Daerah di Kabupaten Siatro. 
5. Nilai dari variabel Pelimpahan Wewenang atau $b_{3}$ adalah positif $(0,112)$. Nilai koefisien regresi $b_{3}$ ini menunjukkan bahwa variabel Pelimpahan Wewenang mempunyai pengaruh hubungan positif dan searah terhadap Kinerja Manajerial secara statistik.

6. Pengujian hipotesis 1 , diperoleh hasil $t_{\text {hitung }}<t_{\text {tabel, }}$, dengan demikian $\mathrm{H}_{\mathrm{a}} 3$ ditolak atau dengan kata lain variabel Pelimpahan Wewenang tidak berpengaruh signifikan terhadap Kinerja Manajerial Dinas Daerah di Kabupaten Siatro.

\section{Saran}

Berdasarkan hasil penelitian, maka dapat dikemukan beberapa saran sebagaimana berikut ini:

1. Untuk meningkatkan pengetahuan pegawai perlu diberikan kesempatan kepada para pegawai yang memenuhi syarat untuk mengikuti studi lanjut.

2. Dari aspek keterampilan para pegawai dapat diikut-sertakan dalam kegiatan-kegiatan pelatihan/kursus yang berkaitan dengan bidang tugas. Setiap unit (eselon) mempunyai karakteristik yang berbeda dengan unit-unit lain, sehingga perlu keterampilan khusus, seperti diklat bendahara, dan lain-lain.

3. Dalam rangka pemenuhan kebutuhan motivasi seyogyanya mengupayakan peningkatan secara kualitas dan kuantitas reward (remunerasi) berdasarkan pencapaian kinerja pegawai.

4. Penggunaan instrumen tidak hanya berupa kuesioner, juga bisa dilakukan wawancara secara langsung dengan narasumbernya, agar hasil yang didapa lebih akurat, tidak terjadi persepsi (pandangan) yang berbeda antara responden dengan peneliti, serta menghindari tidak kembalinya kuesioner.

5. Penelitian selanjutnya diharapkan untuk dapat memperluas variasi populasi dan jumlah sampel, sehingga diharapkan dapat diperoleh hasil penelitian yang lebih baik. Penelitian yang akan datang juga dapat melibatkan seluruh Dinas Daerah dan Lembaga Teknis Daerah di Sitaro. Di samping itu, bisa ditambahkan variabel lain yang mungkin dapat mempengaruhi kinerja manajerial, seperti lingkungan pekerjaan, lamanya bekerja dan lain sebagainya.

\section{DAFTAR PUSTAKA}

Anwar Prabu Mangkunegara. 2010. Evaluasi Kinerja SDM. Hal 61-77.

Ardiani, Ika S., Dian Triyani, dan Anik Puji Lestari. 2011. PC engaruh Partisipasi Penyusunan Anggaran terhadap Kinerja Manajerial dengan Ketidakpastian Lingkungan, Komitmen Organisasi dan Pelimpahan Wewenang sebagai Variabel Moderating (Studi Kasus pada Politeknik Ilmu Pelayaran Semarang). Seminar Nasional Ilmu Ekonomi Terapan Fakultas Ekonomi UNIMUS.

Brownell.P, 1981a. Participation in Budgeting Process; when it works and itu doesn't. Journal of Accounting Literature, Vol 1: 124-153.

1982b. The Role Of Accoutning Data in Performance Evaluation, Budgetery Participation, and Organization Effectivenes. Journal of Accounting Research, Vol 20: 12-27.

Brownell, P dan M, Miclines. 1986. Budgetery Participation, Motivation, and Managerial Performance. The Accounting Review. Vol LXI No. 4. October: 587-600.

Bryan.J.E A Locke. 1967. Goal Setting as a Means of Increasing Motivation, The of Applied Psycology. (June): 274-277.

Depdagri RI. 2007. Permendagri Nomor 30 Tahun 2007 tentang Pedoman Penyusunan Anggaran Pendapatan dan Belanja Daerah Tahun Anggaran 2008.

Desi Winarni. 2013. Pengaruh Partisipasi Dalam Penyusunan Anggaran, Motivasi, Pelimpahan Wewenang, Budaya Organisasi terhadap KinerjaManajerial (Studi Kasus Pada Dinas Dilingkungan Kabupaten Muaro Jambi).

Depdagri RI. 2006. Permendagri Nomor 13 Tahun 2006 tentang Pedoman Pengelolaan Keuangan Daerah.

Ferdinand, Augusty Tae. 2006. Structural Equation Modelling Dalam Penelitian Manajemen. Semarang: Badan Penerbit Universitas Diponegoro.

Frisilia Wihasfina Hafiz. 2007. Pengaruh Partisipasi anggaran terhadap Kinerja Manajerial pada PT Cakra Compact Aluminium Industries. Universitas Negeri Sumatra Utara.

Garrison Noorren, diterjemahkan oleh Totok Budi Santoso.2000. Akuntansi Manajerial. Jakarta; Salemba empat.

Galbraith, J.1973. Designing Complex Organizations. Reading, Mass.: Addison-Wesley Publishing Company.

Ghozali, Imam. 2006. Aplikasi Analisis Multivariate dengan Program SPSS. Edisi 1. Semarang: Badan Penerbit Universitas Diponegoro. 
Gul. F.A., J.S.L Tsui, S.C.C Fong, and H.Y.L Kwok. 1995. Decentralization as A Moderating Factor in the Budgetary Participation - Performance Relationship; Some Hongkong Evidance, Accounting and Business Reserach. Vol 25:107-113.

Goleman, D. 1997. Emotional Intellegence : Why it can matter more than IQ. New York: Bantam Books.

Hansen, Don R. and M.M. Mowen. 2000. Management Accounting. 5th Edition Sount-Western College Publishing.

Hehanussa. 2001. Pengaruh Locus of Control terhadap Hubungan antara Partisipasi Penyusunan Anggaran dengan Kepuasan Kerja dan Kinerja Manajerial.Tesis S2 tidak dipublikasikan. Universitas Diponegoro, Semarang.

Indriantoro, Nur. 1993. An Empirical Study of Locus of Control and Cultural Dimensions as Moderating Variabels of The Effect of Participaive Budgeting on Job Performance and Job Satisfaction. Jurnal Ekonomi dan Bisnis Indonesia. Januari, 15(1), 97-114.

Kennis I. 1997. Effect of Budgetery Goal Charactiristics on Managerial Attitudes And Performance. The Accounting Review. Vol. LIV No. 4 October: 707-721.

Lotta Saarikoski. 2006. The Effect of Cost Management Knowledge on The Relationship between Budgetary Participation and Managerial Performance. The British Accounting Review 38 (2006) No. 427-440.

Mahoney, T A. T,H Jedee \& S J Carroll . 1963. Development of Management Performance : A Research Approach. Cincinnati : South Western Publishing.

Malayu S.P. Hasibuan. 2006. Manajemen Sumber Daya Manusia, Edisi ke-7. Jakarta: PT Bumi Aksara.

Marani dan Supomo. 2003. Motivasi dan Pelimpahan Wewenang Sebagai VariabelModerating Dalam Hubungan Antara Partisipasi Penyusunan Anggaran Dengan Kinerja Manajerial. Journal Riset Akuntasi Indonesia. Vol 2. Januari 2003.

Mardiasmo. 2009. Akuntansi Sektor Publik. Yogyakarta: Penerbit Andi.

Meilani Utami. 2009. Pengaruh Pelimpahan Wewenang dan Motivasi Terhadap Hubungan Antara Partisipasi Penyusunan Anggaran Dengan Kinerja Manajerial; Survey Pada Pejabat Struktural di SKPD Pemerintah Kabupaten Klaten. Universitas Muhammadyah Surakarta.

Mulyadi. 2001. Akuntansi Manajemen: Konsep, Manfaat, \& Rekayasa. Edisi 3. Yogyakarta: Salemba Empat

Munandar.M. 2001. Budgeting, Perencanaan Kerja, Pengkoordinasian Kerja, Pengawasan Kerja. Edisi pertama, BPPE Yogyakarta

Mia.L. 1988. Managerial Atittude, Motivation and Effectiveness of Budget Participation. Accounting Organization and Society. Vol.13 No 5:465-475.

Milani. 1975. The Relationship Of Participation in Budget Setting to Industirial Supervisior Performance and Attitudes: A Field Study. Accounting Review. April P. 274-284.

Mitchell, T,R. 1982. Motivation: New Direction For Theory, Research and Practice. Academy Of Management Review. Vol.7 No 1:80-88.

Nafarin, M. 2000. Penganggaran Perusahaan Edisi I. Jakarta: Salemba Empat.

Nanda Hapsari A R. 2010. Pengaruh Partisipasi Penyusunan Anggaran Terhadap Kinerja Manajerial dengan Komitmen Organisasi dan Locus of Control sebagai Variabel Moderating.Fakultas Ekonomi Universitas Diponegoro Semarang.

Puspaningsih. 2004. Faktor-faktor yang Berpengaruh Terhadap Kepuasan Kerja dan Kinerja Manajer Perusahaan Manufaktur. JAAI Volume 8 No. 1, Juni 2004.

Rinusu dan Sri Mastuti. 2003. Panduan Praktis Mengontrol APBD. Jakarta: Civic Education and Budget Transperency Advocation (CiBa) and Friedrich Ebert Stiftung (FES).

Ritonga, Panangaran. 2008. Pengaruh Budaya Paternalistik dan Komitmen Organisasi terhadap Hubungan antara Partisipasi Anggaran dan Kinerja Manajerial pada PDAM Tirtanadi Provinsi Sumatera Utara. Tesis. Program Magister Akuntansi Sekolah Pascasarjana Universitas Sumatera Utara, Medan.

Riyadi, Slamet. 2000. Motivasi dan Pelimpahan Wewenang sebagai Variabel Moderating dalam Hubungan antara Partisipasi Penyusunan Anggaran dan Kinerja Manajerial. Jurnal Riset Akuntansi Indonesia. Vol. 3 No. 2. Juli. pp. 134-150.

Robbins., S.P. 2001. Perilaku Organisasi: Konsep, Kontroversi, Aplikasi. Jilid 1 Edisi Bahasa Indonesia. Jakarta: Prenhallindo.

Sardjito, Bambang dan Osmad Muthaher. 2007. Pengaruh Partisipasi Penyusunan Anggaran terhadap Kinerja Aparat Pemerintah Daerah: Budaya Organisasi dan Komitmen Organisasi sebagai Variabel Moderating. Artikel yang disampaikan dalam Simposium Nasional Akuntansi (SNA) X Universitas Hasanuddin Makassar. 
Supiyono. 2000. Akuntansi Biaya. Yogyakarta: BPFE

Supomo, B, Nur, Indriantoro. 1998. Pengaruh Struktur dan Kultur Organisasi Terhadap Keefektifan Partisipasi Anggaran dalam Peningkatan Kinerja Manajerial: Studi Empiris Perusahan Manufaktur. Kelolo. No. 18, 61-68.

Surya, Dharma. 2005. Manajemen Kinerja: Falsafah Teori dan Penerapannya, Cetakan I. Yogyakarta: Pustaka Pelajar.

Soetrisno. 2010. Pengaruh Partisipasi, Motivasi, dan Pelimpahan Wewenang, Dalam Penyusunan Anggaran Terhadap Kinerja Manajerial. Studi Empiris Pada Dinas Daerah dan Lembaga Teknis Daerah di Kabupaten Rembang. Universitas Diponegoro.

Undang-Undang Nomor 17 Tahun 2003 tentang Keuangan Negara.

Undang-Undang Nomor 32 Tahun 2004 tentang Pemerintahan Daerah.

Undang-Undang Nomor 33 Tahun 2004 tentang Pemrimbangan Keuangan.

Wibowo. 2007. Manajemen Kinerja Edisi Dua. Jakarta: PT. Rajagrafindo Persada.

Wiryono dan Raharjo. 2007. Pengaruh Karakteristik Personalitas Manajer terhadap Hubungan antara Partisipasi dalam Penyusunan Anggaran dengan Kinerja Manajerial. Kinerja , Vol. 11, No. 1, Tahun 2007 Hal. 50-63.

http://manado.bpk.go.id/ 